\begin{tabular}{|l|l|l|l|l|}
\hline Internat. Rev. Hydrobiol. & $\mathbf{9 2}$ & 2007 & 6 & $647-655$ \\
\hline
\end{tabular}

DOI: 10.1002/iroh.200610979

NANCY HoFer and JoHn S. RichARDSON*, 1

University of British Columbia, Department of Forest Sciences, 3041-2424 Main Mall, Vancouver, British Columbia, V6T 1Z4, Canada; e-mail: John.Richardson@ubc.ca

\title{
Comparisons of the Colonisation by Invertebrates of Three Species of Wood, Alder Leaves, and Plastic "Leaves" in a Temperate Stream
}

key words: biofilm, detritus, woody debris, macroinvertebrates

\begin{abstract}
Small woody debris in streams is abundant, and may be a food source or may provide a substrate on which other food sources such as biofilm may develop, both of which may be significant to invertebrates in times of food scarcity. We examined patterns of invertebrate colonisation of small woody debris (veneers of red alder, Douglas-fir, and western red cedar), red alder leaves, and plastic (as an inert substrate to mimic leaves). Invertebrate colonisation was high on alder leaves, but low on wood substrates and plastic, controlling for the available surface area. Detritivorous invertebrates had significantly higher colonisation rates of alder leaves versus the other four substrates, whereas predators and collectors did not (consistent with their use of these as substrates and not food). All wood decreased in mass by $<15 \%$ and leaves by $\sim 50 \%$ over the 75 days of the experiment. For all taxa tested, there was no significant difference in their colonisation of the wood veneers versus the plastic sheets. These results suggest that wood was not directly used by these invertebrates as a food source, or that there could be similar biofilm development on the surfaces of these substrates.
\end{abstract}

\section{Introduction}

Large wood is an important structural element in streams of temperate regions, and a number of studies have identified linkages between wood and invertebrate community composition (CARlson et al., 1990; Lemly and Hilderbrand, 2000; Collier and SMith, 2003). In-stream wood has been found to be heavily colonised by invertebrates (BENKE et al., 1984), and HAX and GolLADAY (1993) found that invertebrate densities were greater on wood substrates than on leaves. In these studies sessile invertebrates benefited the most from large wood as a stable substrate to which they could attach. The standing stock of large and small wood fragments is quite large in most small, forested streams, especially relative to the biomass of leaves generally present (DUdLEY and ANDERSON, 1982; NAIMAN et al., 2000; KARLSSON et al., 2005; WIPFLI et al., 2007).

Small woody debris may also be of importance to aquatic invertebrates. It is a source of biologically-fixed energy to stream food webs. Wood is more biologically stable (Gulis et al., 2004) and less seasonal (PETERSEN et al., 1989) than other kinds of detritus, and studies have demonstrated that wood can serve as a food source for some species of stream invertebrates (ANDERSON et al., 1979; DudLEY and ANDERSON, 1982, 1987; BonDAR et al., 2005). However, few studies have looked at the nutritional significance of small

* Corresponding author 
woody debris in stream ecosystems, whereas the predominant focus has been on leaves as a food resource in these systems (e.g., RICHARDSON, 1991, 1992; WALLACE et al., 1999).

Wood may provide a very large surface area that allows for biofilm development, another important food source for invertebrates. ANDERSON and CUMMINS (1979) pointed out that most of the nutrition derived from feeding on leaves is from the microbes and associated biofilm, not the leaf tissue itself. Other studies have shown that wood can support higher fungal production and microbial biomass than leaf litter (BENKE et al., 1984; HAX and GoLLADAY, 1993). Furthermore, the wood itself may also be a major carbon source which may significantly contribute to long-term carbon availability and nutrient spiralling as suggested by HARMON et al. (1986). Therefore, wood may provide an important food resource for invertebrates directly or via support of biofilm development.

Wood may be of particular importance as a food source in times of resource scarcity such as during the summer months before the fall input of leaf detritus or in areas or times of high stream discharge where leaves may locally become dislodged from the reach (ANDERSON and SEDELl, 1979; PECKARSKY, 1980). During summer months, when invertebrate production can be high (RICHARDSON, 2001), invertebrates may have to become facultative feeders, utilising substitutable food sources, possibly fragments of wood (e.g., HoFFMANN, 2000; BONDAR et al., 2005).

Whichever use(s) invertebrates may make of small woody debris, it is expected that colonisation rates will differ between various substrates, thereby influencing local invertebrate abundance (ROWE and RICHARDSON, 2001). Activities that modify streamside vegetation, such as forestry, will alter the nature of leaf and wood inputs, and thereby influence the abundance and community composition of aquatic invertebrates (LEMLY and HILDERBRAND, 2000; LECERF et al., 2005).

We sought to determine if invertebrates differentially colonised wood veneers (commercially available, thin sheets of wood often used for finished surfaces of building materials or for laminates) of 3 different species, alder leaves, and an inert substrate (plastic). We expected that alder leaves would be readily colonised by invertebrates, and hence we included leaves for comparative purposes. We hypothesised that wood could be a potential food source and predicted that we would find higher numbers of shredder-detritivores on wood than on the plastic leaf mimics (a control for substrate area). We also predicted that wood from a deciduous species (alder) would be colonised by invertebrates faster than coniferous species, based on differences in the resistance of the various species to breakdown. We expected that there should be no differences in colonisation by predators and scrapers between any of the substrates.

\section{Methods}

\subsection{Site Description}

The experiment took place in a second order stream (stream G in KIfFNeY et al., 2003) in the University of British Columbia's Malcolm Knapp Research Forest located approximately $60 \mathrm{~km}$ east of Vancouver, British Columbia. The forest is situated in the Coastal Western Hemlock biogeoclimatic zone. The canopy vegetation consists primarily of Douglas-fir (Pseudotsuga menziesii), western hemlock (Tsuga heterophylla), western red cedar (Thuja plicata), and red alder (Alnus rubra), with an understory of vine maple (Acer circinatum) and salmonberry (Rubus spectabilis) in the riparian areas. The forest at the site regenerated following a fire in 1931, and trees had an average diameter at breast height of $40 \mathrm{~cm}$ and an average height of $45 \mathrm{~m}$. The stream's bankfull width was approximately $4 \mathrm{~m}$ and the benthic substrate consisted predominantly of cobbles, gravel, and sand, with a little exposed bedrock. Summer base flow and stream gradient were $0.6 \mathrm{l} / \mathrm{s}$ and $6 \%$, respectively. Flows were low at the time of sampling. 


\subsection{Sampling Design and Procedures}

All the substrates were added on 18 July 2002 and samples were removed approximately every two weeks resulting in five sample dates, with the last collection on 1 October 2002. Four replicates of each of the five substrates were collected on each sampling date for a total of 100 samples over the experiment. Replicates for a given date and treatment were placed in different pools $(n=4)$ of similar characteristics along a $25 \mathrm{~m}$ reach of the stream.

We used untreated, unconditioned wood veneers of Douglas-fir, red alder and western red cedar, red alder leaves (collected the previous year after abscission and air-dried), and plastic mimics as the five substrates. These tree species are common along streams in coastal British Columbia and contribute to the substantial standing stock of wood in streams. Red alder leaves were included for comparison to wood substrates and to other studies. Plastic of colour similar to the wood was used as a control for surface area and texture (i.e., microhabitat) of the wood. Ten $5.1 \mathrm{~cm} \times 12.7 \mathrm{~cm}$ veneers (approximately $1 \mathrm{~mm}$ in thickness) were used in each wood sample for a total surface area (including both sides) of $1290.3 \mathrm{~cm}^{2}$. Plastic pieces were cut to similar dimensions. A relation for dry mass to area was developed for alder leaves to adjust the amount of leaves to be equivalent in surface area to the wood and plastic substrates. All substrate materials were loosely placed in hairnets (mesh size $1 \mathrm{~cm}^{2}$ ) and secured in the stream with fishing line and weighed down to the stream bed with rocks.

Samples were removed from the stream with a fine mesh net held downstream of the sample to catch any dislodged invertebrates. Samples were placed in a sample jar and preserved in formalin. All samples were disassembled over a $60 \mu \mathrm{m}$ sieve, substrates were gently washed with tap water, and the hairnets were examined visually for invertebrates. Due to a labelling error, cedar veneers for day 14 were discarded, although not the invertebrates. Invertebrates were identified to the lowest taxon possible. Substrates, with the exception of plastic, were dried at $50{ }^{\circ} \mathrm{C}$ for a minimum of $48 \mathrm{~h}$, weighed, ashed in a muffle furnace at $550^{\circ} \mathrm{C}$ for a minimum of $2 \mathrm{~h}$, and weighed again.

\subsection{Data Analysis}

Data were analysed with treatment (i.e., substrate) and time as main effects, along with their interaction, in a two-way ANOVA using PROC MIXED (SAS version 9.1). The response measures were substrate dry mass remaining, as well as total invertebrate numbers and selected taxa for which there were sufficient numbers for analysis. All invertebrate numbers were expressed as number per sample, as surface area was controlled for in each sample unit. We included some taxa that were predicted to be associated with wood and some that would not use wood as anything more than a physical substrate (e.g., predators). We chose ANOVA over ANCOVA as the responses through time were clearly not linear. We used pre-planned contrasts to compare the three wood types versus either the red alder leaves, or the plastic control (two separate contrasts). The three wood types were compared using probability of difference of the mean squares from the general linear model from PROC MIXED. In all tests, an $\alpha$ of 0.05 was used for statistical significance.

\section{Results}

\subsection{Substrate Mass Loss and Total Invertebrate Numbers}

The ash-free, dry mass remaining (g AFDM) decreased with time (Fig. 1). Douglas-fir lost the least amount of mass followed by cedar, alder wood, and alder leaves. Cedar wood had a slightly higher mass after being submerged for 42 days. No wood substrate lost more than $15 \%$ of its original mass after 75 days, whereas leaves decreased in mass by approximately $50 \%$ over the same time period.

The colonisation of substrates by all invertebrates combined showed significant patterns with respect to treatment and sampling date (Table 1, Fig. 2a). Numbers of total invertebrates showed peaks at intermediate dates compared to the beginning and end dates of the trials, and there was a pattern of decreasing numbers towards the later dates. Throughout, alder 


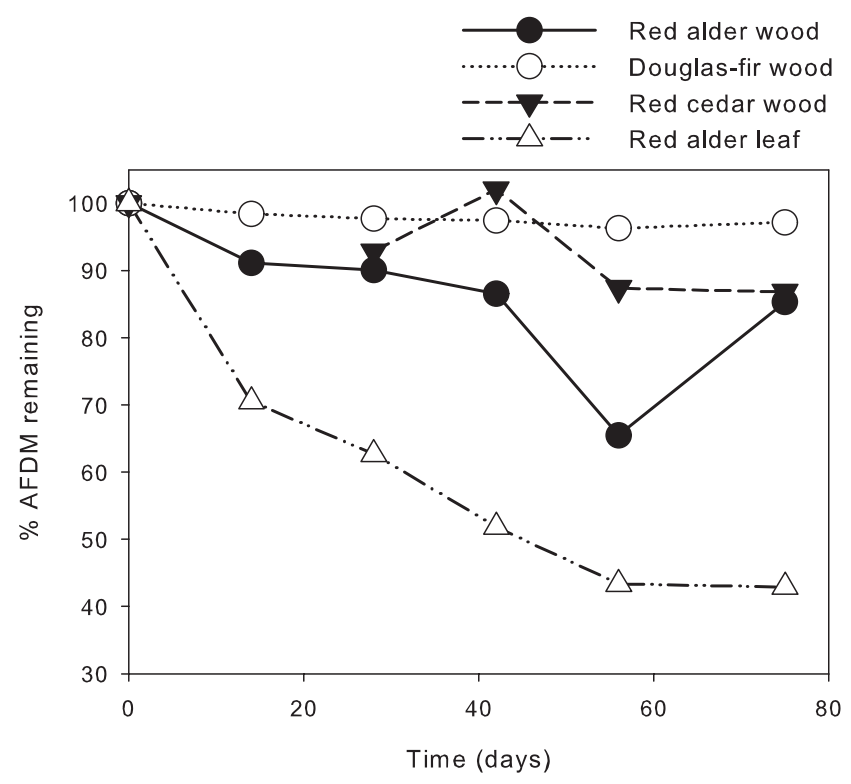

Figure 1. Percentage of substrate ash free dry mass (AFDM) remaining as a function of time submerged in the stream. All substrates were added at the start and removed on subsequent sampling days $(14,28,42,56$ and $75 \mathrm{~d})$.

leaves had higher numbers ( 2 times as many invertebrates, based on least squared mean value for leaves of 118.1) than the three wood veneers, although the differences were significant only for the first two sampling periods (28 days) (Table 1, Fig. 2a). The contrast of plastic versus the wood veneers showed no significant effect for any response measure (Table 1). Comparisons of the three wood types against each other showed no significant differences in numbers of any invertebrates.

Table 1. Summary of ANOVA results for contrasts between treatments. In each case the denominator $d . f$. was 50. $F$-values in bold indicate significant effects and asterisks indicate probability levels: $* P<0.05, * * P<0.01, * * * P<0.001$. $F$-values without asterisks indicate no significant effect.

\begin{tabular}{|c|c|c|c|c|c|}
\hline Taxon & $\begin{array}{l}\text { Treatment } \\
\quad(4 \text { d.f. })\end{array}$ & $\begin{array}{l}\text { Day } \\
(4 \text { d.f. })\end{array}$ & $\begin{array}{l}\text { Treatment } \times \text { Day } \\
\quad(16 \text { d.f. })\end{array}$ & $\begin{array}{l}\text { Wood } \\
\text { versus alder } \\
\text { leaves }\end{array}$ & $\begin{array}{c}\text { Wood } \\
\text { versus plastic }\end{array}$ \\
\hline Total numbers & $16.53 * * *$ & $10.71 * * *$ & $3.81 * * *$ & $\mathbf{5 0 . 9}$ *** & 1.36 \\
\hline Paraleptophlebia & $13.76 * * *$ & $17.87 * * *$ & $3.65 * * *$ & $40.97 * * *$ & 0.26 \\
\hline Lepidostoma & 14.16*** & $4.04 * *$ & $1.95 *$ & 48.39*** & 1.47 \\
\hline Chironomidae & $10.81 * * *$ & $9.12 * * *$ & $5.1 * * *$ & $29.13 * * *$ & 0.6 \\
\hline Nemouridae & $2.63 *$ & 2.92* & 2.04* & $8.37 * *$ & 0.38 \\
\hline Polycentropus & 0.6 & $5.75^{* * *}$ & $1.94 *$ & 1.12 & 0.01 \\
\hline Acari & 1.69 & 3.06* & 1.16 & 1.95 & 1.12 \\
\hline Oligochaeta & 1.85 & 1.57 & 1.37 & 0.09 & 0.87 \\
\hline Ceratopogonidae & 0.89 & 1.35 & 0.89 & 0.69 & 0.49 \\
\hline
\end{tabular}



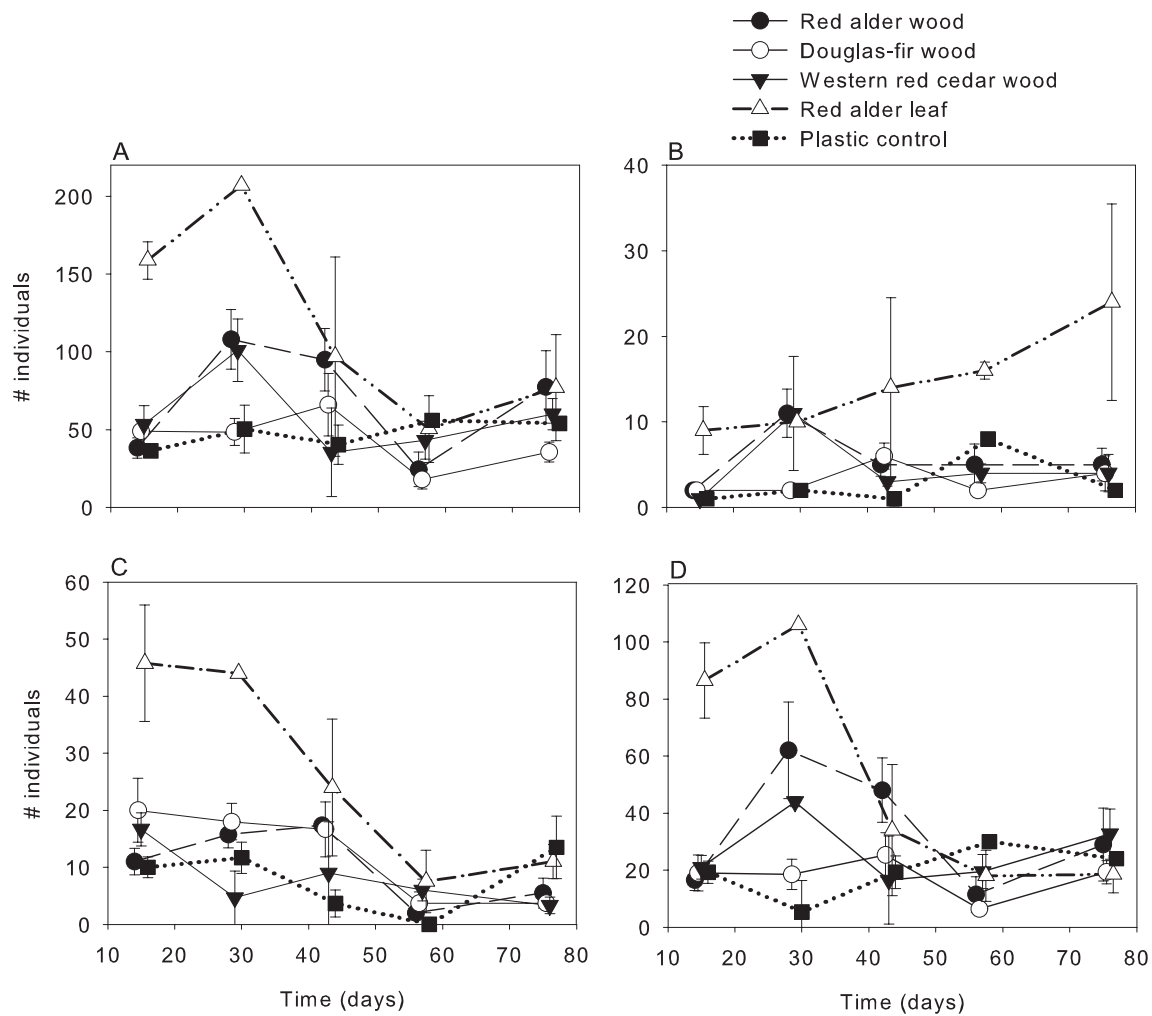

Figure 2. Mean numbers $( \pm 1$ S.E. $)$ of invertebrates per sample unit on the 5 different substrate types as a function of time submerged in the stream. A. Total numbers of invertebrates. B. Lepidostoma (shredder). C. Paraleptophlebia (collector-gatherer). D. Chironomidae larvae. Points are slightly off-set for each date to make the data clearer.

\subsection{Substrate Use by Specific Taxa}

Some taxa were sufficiently abundant to analyse for patterns of colonisation of the various substrates. There were significantly more (3.6 times as many) larvae of the shredding caddisfly Lepidostoma (Trichoptera) on leaves than on all other substrates over most of the sampling period (least squared mean value for leaf substrate $=14.4$ ) (Table 1, Fig. 2b). This genus demonstrated less variation across the entire sampling period than did either the detritivorous mayfly Paraleptophlebia spp. (Ephemeroptera) or total number of invertebrates (Table 1). As with other taxa, there was no significant difference between the numbers on plastic versus the three types of wood (Table 1). There were more Lepidostoma on alder wood (5.5), followed by cedar (4.4), Douglas-fir (3.3), and finally plastic (2.8) (Fig. 2b). There was also no significant difference in the numbers of Lepidostoma between any of the three wood types.

For Paraleptophlebia (primarily P. temporalis) larvae, there were significant differences due to treatment, date, and their interaction (Table 1, Fig. 2c). There was a significant contrast between leaves and the three wood veneers (Table 1), but there was no significant difference between wood and plastic. As with the total number of invertebrates, leaves had 
more Paraleptophlebia (2.6 times as many, least squared mean $=26.5)$ than all other substrates, followed by Douglas-fir wood (12.4), alder wood (10.3), plastic (9.1), and with the smallest number on cedar wood (7.9) (Fig. 2c). There was no significant difference between any of the three wood types based on a posteriori comparison of the least squared means.

The larvae of the detritivorous stonefly family Nemouridae (primarily early instars of Zapada cinctipes, Z. haysi and Visoka cataractae - all combined here) also showed significant effects of treatment, date, and the interaction (Table 1). As with the other detritivores above, nemourids were significantly more abundant on alder leaves ( 2.5 times as many) than on the three wood veneers (Table 1). And as with the other taxa, there was no significant difference between the plastic and the three wood veneers (Table 1).

The number of chironomid larvae (Diptera) did not differ significantly between wood and plastic (Table 1), or between the three types of wood. However, the total numbers of chironomids were significantly higher on leaves than on other substrates for the first 28 days (Table 1, Fig. 2d). Total chironomid numbers were three and nine times greater on wood substrates than Paraleptophlebia or Lepidostoma numbers, respectively.

We also tested several taxa that we expected would not use wood as a potential food substrate, and that were common enough to allow for statistical tests. Polycentropus larvae (Trichoptera: Polycentropodidae), Acari, Oligochaeta, and Ceratopogonidae (Diptera) showed no significant effects of treatment (Table 1). There was no interaction between treatment and date, with the exception of Polycentropus, but this effect was weak. None of these four taxa showed a significant contrast between the numbers on the wood veneers versus alder leaves, or versus the plastic (Table 1).

\section{Discussion}

The lack of significant differences between the colonisation of wood versus plastic, or between different species of wood, suggests that invertebrates were using the wood and plastic primarily for their physical features as substrates or perhaps for surface biofilms. For most invertebrate taxa there were significantly higher numbers that colonised leaves in this experiment, consistent with the use of leaves primarily as a food source (DoBson et al., 1992; RichARDSON, 1992). All substrates were equally available to the same pool of potential colonists, so differences reflect differential rates of colonisation.

Although relative rates of substrate breakdown were as predicted (alder leaves $>$ alder wood > coniferous wood) (GOLLADAY and WEBSTER, 1988), invertebrate colonisation and use of the different wood species generally did not reflect these differences. KAUFMAN and KING (1987) did not detect significant differences in invertebrate colonisation of pieces of Fraxinus and Populus wood, while TANK and WEBSTER (1998) noted similar microbial activity on various wood species suggesting little difference between wood species. HAX and GOLLADAY (1993) found that collector/gatherers, which formed the largest group in pools in their study, preferred leaves, while filterers, predominantly found in riffles, preferred wood. Preference for wood by some invertebrates may be linked to specific functions of wood related to physical characteristics of their habitats. In our study we examined invertebrates in pools, and we found mostly shredders and gatherers, and few filter-feeders present on our substrates. BOULTON and LAKE (1992) found positive relations between the densities of detritivores and their food resources in riffles, yet found few significant relations in pools which they interpreted as an 'over-abundance' of detritus in the depositional areas. Previous work in our streams has demonstrated that detritus is usually a limiting resource during summer, regardless of channel unit type (RICHARDSON, 1991). 


\subsection{Substrate Preference of Specific Taxa}

We expected significant differences in numbers of shredders (detritivores) as a function of substrate type, but not for other feeding groups. This is because shredders could be using the leaves and wood as a food source itself, while other groups would presumably be using the substrates for their physical features (DOBSON et al., 1992; RICHARDSON, 1992), or feeding on biofilms growing on their surfaces (LEDGER and HiLDREw, 2001). Our results for detritivores indicated that leaves served as food (and substrate), whereas densities on wood veneers and plastic were similar to each other and much lower than for leaves. These observations were consistent for Paraleptophlebia, Lepidostoma, and nemourids. We did not find many larvae of the elmid beetle, Lara sp., on our substrates, although they are present, perhaps because the wood veneers we used may have been too thin for this wood-gouging genus. From our experiment we cannot distinguish between use of wood or plastic by these taxa for their value as a substrate or as a potential source of biofilm.

Some species are known to be able to variously consume leaf litter or biofilm. LEDGER and HILDREW (2001) demonstrated that nemourid stonefly larvae can grow at normal rates on biofilms growing on cobble substrates, despite generally being associated with consumption of leaf detritus. DUDLEY and ANDERSON (1982) found that Nemouridae existed on both leaves and wood in similar abundances. High numbers of chironomids on wood and plastic substrates in this study may also indicate use of these surfaces for a source of biofilm. Polycentropus caddisflies, Acari, Oligochaeta, and Ceratopogonidae were not expected to use wood as food, and may select them simply as a surface, or perhaps for other values, including a source of prey or other foods.

\subsection{Invertebrate Colonisation Trends}

Colonisation through time was complex, as in other studies (e.g., ANDERSON, 1989; HAX and Golladay, 1993; DruRy and Kelso, 2000), with some species colonising rapidly and then possibly being displaced (RICHARDSON, 1992). The results for the plastic substrate showed the greatest total number of invertebrates on the final sampling date. As the use of plastic for its physical features should remain constant over time, the increasing colonisation with time might suggest that biofilm development (ARSUFFI and SUBERKROPP, 1985; TANK and WEBSTER, 1998) was important to colonisation. Also, our study was relatively short term, given that in a 5 to 6 year long study of colonisation and degradation of wood dowels by ANDERSON (1989), numbers of invertebrates on wood substrates did not stabilise until between the first and second year.

Our results showed that wood veneers were no more likely to be colonised than plastic mimics, and may provide little more than a substrate. The large amounts of wood in many streams, particularly of the Pacific Coast of North America (RICHARDSON et al., 2005), may contribute a large surface area to biofilm development, although this has not been quantified. Except for specialised consumers of wood (e.g., Lara avara and Lipsothrix spp. [DuDLEY and ANDERSON, 1987]), wood may be incidental to the diets of other consumers. However, wood may be a substitutable resource for stream detritivores as seen in the frequency with which consumers contain particles of wood (ANDERSON et al., 1979; BONDAR et al., 2005). While stream invertebrates are clearly associated with and consume wood, the quantitative nutritional contribution of wood to stream food webs is still not known. 


\section{Acknowledgements}

We are grateful for the support of the Natural Sciences and Engineering Research Council (Canada) and the University of British Columbia for support of our research. We thank the staff of the Malcolm Knapp Research Forest for their help. The contributions of Kenton Stewart to the presentation of this manuscript are greatly appreciated. We are very thankful to TATIANA LEE and KATHERINE BOTTRIELL for their field and lab assistance.

\section{References}

Anderson, N. H. and K. W. Cummins, 1979: Influences of diet on the life histories of aquatic insects. J. Fish. Res. Board Can. 36: 335-342.

Anderson, N. H., J. R. Sedell, L. M. Roberts and F. J. TRISKA, 1979: The role of aquatic invertebrates in processing of wood debris in coniferous forest streams. - Am. Midl. Nat. 100: 64-82.

ANDERSON, N. H. and J. R. SEDELl, 1979: Detritus processing by macroinvertebrates in stream ecosystems. - Ann. Rev. Entomol. 24: 351-378.

Anderson, N. H., 1989: Xylophagous Chironomidae from Oregon streams. - Aquat. Insects 11: 33-45.

Arsuffi, T. L. and K. Suberkropp, 1985: Selective feeding by stream caddisfly (Trichoptera) detritivores on leaves with fungal-colonized patches. - Oikos 45: 50-58.

Benke, A. C., T. C. Van Arsdall Jr., D. M. Gillespie and F. K. Farrish, 1984: Invertebrate productivity in a subtropical blackwater river: the importance of habitat and life history. - Ecol. Monogr. 54: $25-63$

Bondar, C. A., K. Bottriell, K. Zeron and J. S. Richardson, 2005: Does trophic position of the omnivorous signal crayfish (Pacifastacus leniusculus) in a stream food web vary with life history stage or density? - Can. J. Fish. Aquat. Sci. 62: 2632-2639.

Boulton, A. J. and P. S. LAKE, 1992: Benthic organic matter and detritivorous macroinvertebrates in two intermittent streams in south-eastern Australia. - Hydrobiologia 241: 107-118.

Carlson, J. Y., C. W. Andrus and H. A. Froehlich, 1990: Woody debris, channel features, and macroinvertebrates of streams with logged and undisturbed riparian timber in Northeastern Oregon, USA. - Can. J. Fish. Aquat. Sci. 47: 1103-1111.

Collier, K. J. and E. J. Bowman, 2003: Role of wood in pumice-bed streams 1: Impacts of post-harvest management on water quality, habitat and benthic invertebrates. - Forest Ecol. Manage. 177: 243-259.

Collier, K. J. and B. J. Smith, 2003: Role of wood in pumice-bed streams 2: Breakdown and colonization. - Forest Ecol. Manage. 177: 261-276.

Dobson, M., A. G. Hildrew, A. Ibbotson and J. Garthwaite, 1992: Enhancing litter retention in streams: do altered hydraulics and habitat area confound field experiments? - Freshw. Biol. 28: 71-79.

Drury, D. M. and W. E. Kelso, 2000: Invertebrate colonization of woody debris in coastal plain streams. - Hydrobiologia 434: 63-72.

DudLEY, T. and N. H. ANDERSON, 1982: A survey of invertebrates associated with wood debris in aquatic habitats. - Melanderia 39: 1-21.

DudLey, T. L. and N. H. ANDERSON, 1987: The biology and life cycles of Lipsothrix spp. (Diptera: Tipulidae) inhabiting wood in western Oregon streams. - Freshw. Biol. 17: 437-451.

Golladay, S. W. and J. R. WebSter, 1988: Effects of clear-cut logging on wood breakdown in Appalachian mountain streams. - Am. Midl. Nat. 119: 143-155.

Gulis, V., A. D. Rosemond, K. Suberkropp, H. S. Weyers and J. P. Benstead, 2004: Effects of nutrient enrichment on the decomposition of wood and associated microbial activity in streams. - Freshw. Biol. 49: 1437-1447.

Harmon, M. E., J. F. Franklin, F. J. Swanson, P. Sollins, S. V. Gregory, J. D. Lattin, N. H. Anderson, S. P. Cline, N. G. Aumen, J. R. Sedell, G. W. Lienkaemper, K. Cromack Jr. and K. W. CumMINS, 1986: Ecology of coarse woody debris in temperate ecosystems. - Adv. Ecol. Res. 15: 133-302.

Hax, C. L. and S. W. Golladay, 1993: Macroinvertebrate colonization and biofilm development in a boreal river. - Freshw. Biol. 29: 79-87.

Hoffmann, A., 2000: The association of the stream caddisfly Lasiocephala basalis (KoL.) (Trichoptera: Lepidostomatidae) with wood. - Int. Rev. Hydrobiol. 85: 79-93. 
Karlsson, O. M., J. S. Richardson and P. M. Kiffney, 2005: Modelling organic matter dynamics in headwater streams of south-western British Columbia, Canada. - Ecol. Model. 183: 463-476.

Kaufman, M. G. and R. H. KING, 1987: Colonization of wood substrates by the aquatic xylophage Xylotopus par (Diptera: Chironomidae) and a description of its life history. - Can. J. Zoology 65 : 2280-2286.

KiffNey, P. M., J. S. Richardson and J. P. Bull, 2003: Responses of periphyton and insects to experimental manipulation of riparian buffer width along forest streams. - J. Appl. Ecol. 40: 1060-1076.

Lecerf, A., M. Dobson, C. K. Dang and E. Chauvet, 2005: Riparian plant species loss alters trophic dynamics in detritus-based stream ecosystems. - Oecologia 146: 432-442.

LEDGER, M. E. and A. G. HiLdREw, 2001: Growth of an acid-tolerant stonefly on epilithic biofilms from streams of contrasting pH. - Freshw. Biol. 46: 1457-1470.

Lemly, A. D. and R. H. Hilderbrand, 2000: Influence of large woody debris on stream insect communities and benthic detritus. - Hydrobiologia 421: 179-185.

Naiman, R. J., R. E. Bilby and P. A. Bisson, 2000: Riparian ecology and management in the Pacific Coastal Rain Forest. - BioScience 50: 996-1011.

PeCKARsky, B. L., 1980: Influence of detritus upon colonization of stream invertebrates. - Can. J. Fish. Aquat. Sci. 37: 957-963.

Petersen, R. C., K. W. Cummins and G. M. Ward, 1989: Microbial and animal processing of detritus in a woodland stream. - Ecol. Monographs 59: 21-39.

RiCHARDSON, J. S., 1991: Seasonal food limitation of detritivores in a montane stream: an experimental test. - Ecology 72: 873-887.

RichARDSON, J. S., 1992: Food, microhabitat, or both? Macroinvertebrate use of leaf accumulations in a montane stream. - Freshw. Biol. 27: 169-176.

RichaRdSON, J.S., 2001: Life cycle phenology of common detritivores from a temperate rainforest stream. - Hydrobiologia 455: 87-95.

Richardson, J. S., R. E. Bilby and C. A. Bondar, 2005: Organic matter dynamics in small streams of the Pacific Northwest. - J. Am. Water Resources Assoc. 41: 921-934.

Rowe, L. and J. S. RichARDSON, 2001: Community responses to experimental food depletion: resource tracking by stream invertebrates. - Oecologia 129: 473-480.

TANK, J. L. and J. R. WEBSTER, 1998: Interaction of substrate and nutrient availability on wood biofilm processes in streams. - Ecology 76: 2168-2179.

Wallace, J. B., S. L. Eggert, J. L. Meyer and J. R. Webster, 1999: Effects of resource limitation on a detrital-based ecosystem. - Ecol. Monogr. 69: 409-442.

Wipfli, M. S., J. S. Richardson and R. J. NAiman, 2007: Ecological linkages between headwaters and downstream ecosystems: transport of organic matter, invertebrates, and wood down headwater channels. - J. Am. Water Resources Assoc. 43: 72-85.

Manuscript received May 31st, 2006; revised April 16th, 2007; accepted May 12th, 2007 